\title{
Další dvojskvost z Kabinetu pro studium českého divadla IU-DÚ
}

\author{
Pavel Drábek
}

Eva Šormová a kolektiv. Česká divadelni encyklopedie: Česká činohra 19. a začátku 20. století. Praha: Institut umění - Divadelní ústav a Academia, 2015. 2 svazky; celkem 1296 stran.

Na sklonku roku 2015 vydal Kabinet pro studium českého divadla pod vedením hlavní redaktorky Evy Šormové monumentální, dvojdílný slovník věnovaný české činohře 19. a začátku 20. století. Po encyklopedii divadelních souborů (2000), Českém tanečnim slovniku (2001), Hudebnim divadle $v$ českých zemich. Osobnosti 19. stoleti (2006) a české a německojazyčné upravené redakci encyklopedie Staršího divadla v českých zemich do konce 18. století (česká verze 2007; německá redakce 2013) vychází šestý svazek, a to hned o dvou dílech.

Recenzovat výsledek dlouholeté týmové práce předních českých divadelních historiků ve velkolepém pojetí České divadelní encyklopedie je věc jednak snadná a jednak obtížná. Snadná proto, že lze mnoho chválit, v úctě obdivovat či se zalíbenou fascinací promýšlet; obtížná proto, že lze sotva adekvátně pojmout a ocenit tento olbřímí výsledek v několika odstavcích (natož pak hledat nějaké nedostatky - na což hned zkraje rezignuji; marná snaha). Toto je ve všech ohledech fundamentální práce a moderní historiografický stavebný kámen v poznání české kultury a divadla jako jejího (bez nadsázky) klenotu. Pocta, která se tu českému divadlu podává, je velkolepá a důstojná.

Slovník nadpisuje, že je věnován činohře. To však není zcela pravda - přesahy do jiných divadelních žánrů a oborů jsou velmi časté. Tak se vedle herců, režisérů, ředitelů společností, dramaturgů a dramatiků vyskytují i další klíčové osobnosti - etnograf a sběratel lidových her Julius Feifalík, historik divadla a editor her Ferdinand Menčík, knihkupci a nakladatelé Ignác Leopold Kober či Jan Hostivít Pospíšil, divadelní malíř (např. Angelo Quaglio), divadelní intendant Alois Pravoslav Trojan, překladatel Sofokla Josef Končinský, divadelní kritici a publicisté Josef Krasoslav Chmelenský či ochotnický divadelník, občasný překladatel a především kritik Ignát Herrmann. To je záběr úctyhodný a znamenitý: ukazuje divadlo nejen jako artefakt - tu podívanou, co předvádí „bídný toliko kejklír, I Jenž se hodinku na dívadle namáhal“ (Macbeth 5.4.46-47; př. J. J. Kolár) - ale také jako organismus, ekonomický a obecně kulturní faktor. Zahrnutí těchto dalších profesí je nesmírně důležité.

Podobně velice oceňuji, že tu jsou zařazeni loutkáři - Jan Flachs, František Hanuš, rozkošatělá rodina Kopeckých, Josef Meissner a další (chybí tu však západočeský Karel Novák!) - a pak také významní ochotníci: a to nejen versatilní Ignát Herrmann, ale také východočeský dramatik píšící pro ochotníky František Josef Janke nebo pojizerský ochotník Věnceslav Metelka.

Dva otazníky přesto mám. (1) V pokrytém období se vyskytují jistě i případy anonymní či pseudonymní. Do Staršího divadla 
takové případy zahrnuty jsou; v tomto svazku ovšem nikoli. Je to úmyslné? (2) V úvodu Eva Šormová vysvětluje rozčlenění divadelníků do jednotlivých údobí - takže kupříkladu Václav Thám či Prokop Šedivý jsou zařazeni v tomto díle, nikoli ve Starším divadle a Jaroslav Kvapil na rozdíl od své ženy Hany si musí počkat na svazek další. Tyto případy chápu. Překvapující ovšem je, že například Jiří Karásek ze Lvovic (1871-1951) je zařazen v současném svazku, zatímco divadelní překladatel a literát Bohdan Kaminský (vl. jm. Karel Bušek; 1859-1929) tu zařazen není a patrně bude v díle následujícím. Onen druhý dotaz má ale své důsledky - a kdyby šlo jen o to, že bude heslo v jiné knize, je to maličkost. Jde ale ovšem o víc, jak zmíním níže.

$\mathrm{Na}$ dalších svazcích se už pracuje: $N \check{e}$ mecká činohra v českých zemích v 19. století (garant Berenika Urbanová), Česká činohra 1900-1945 (garant Petra Ježková) a Česká činohra 1945-1989 (garant Martin J. Švejda). Přesto se významně mění celý projekt jako takový. Jak ve své zprávě v posledním loňském čísle Divadelni revue podala Petra Ježková, intence v současnosti prochází zásadní proměnou, která vyplývá spíše z vnějších daností a trendů, jež hrají ve prospěch elektronických medií. Dlouhodobý lexikografický výzkum završený knihou dnes již nenachází donátora (čeští poskytovatelé grantů - Grantová agentura ČR ani Ministerstvo kultury - takové projekty nadále nepodporují). Pokračováním velkoryse proponované řady slovníkových prací, která by obsáhla české profesionální divadlo v celé jeho historické rozloze a žánrovém spektru, tak jak si ji kdysi vytyčili pracovníci Kabinetu pro studium českého divadla, je tedy encyklopedie.
Tedy následující svazky budou, ale výhradné elektronicky! Na jednu stranu je zprávou desetiletí, že se Česká divadelni encyklopedie postupně dostává na internet (viz http:// encyklopedie.idu.cz/). Na stranu druhou je velká chyba, že by se takto fundamentální výzkum zcela zakladatelského rázu měl přesunout do virtuální, klikatelné sféry. Je tedy mnoho co slavit - znamenitý dvojskvost a elektronická publikace starších svazků. Zároveň si dovoluji zakončit jinak:

Apel na Ministerstvo kultury ČR: Vážené Ministerstvo kultury ČR, prospějte prosím ještě více české knižní, divadelní a vůbec intelektuální kultuře a zavažte se podpořit knižni, hmotné vydání následujících svazků České divadelni encyklopedie. Všichni, kdož jsme alespoň třicátníci, máme doma staré diskety a nefunkční CD, na kterých stojí "Life Data“ nebo „Life-Long Guarantee“ a podobně. Pokaždé, když na ně pohlédneme, tak si se slzou v oku a píchnutím u srdce povzdechneme, jak ten jejich „Life“ rychle minul. Podobně jako ve votivních službách středověku, tak v digitální éře trvá věčnost zhruba 20 let. Proto si dovoluji apelovat na význam kultury a jejího hmotného dědictví, které se přece jen hưře maže, vypíná, přepisuje, aktualizuje, kopíruje či systémově chybně zobrazuje. Od dob Gutenbergových a déle se zatím, tuším, nestalo, že by kniha zahlásila: „Connection Error“ nebo „Chyba připojení v síti“ nebo „Server neodpovídá. Vyčkejte."

Podpořte knižní vydání. Investice do České divadelni encyklopedie se bude zúročovat dlouho - jak znám divadelní historiografii a historiky, bude to počínání bez konce.

DOI: 10.5817/TY2016-1-17 